\title{
KAJIAN PERENCANAAN PENDIDIKAN ORANG DEWASA PADA PROGRAM KESETARAAN PAKET C PKBM JAYAGIRI LEMBANG
}

\author{
Mustangin \\ Pendidikan Luar Sekolah, Universitas Pendidikan Indonesia \\ e-mail: mustangin1992@gmail.com
}

\begin{abstract}
Abstrak
Penelitian ini bertujuan untuk mengungkap proses perencanaan pembelajaran berbasis pendidikan orang dewasa pada penyelenggaraan Program Kesetaraan Paket $\mathrm{C}$ atau setara Sekolah Menengah Atas (SMA). Metode yang digunakan dalam penelitian ini adalah kualitatif dengan jenis penelitian adalah studi kasus. Temuan penelitian ini menunjukan bahwa pembelajaran yang diterapkan dalam program kesetaraan paket $\mathrm{C}$ dilakukan dengan pendekatan orang dewasa dengan karakteristik peserta didiknya adalah orang dewasa. Kegiatan perencanaan yang dilakukan oleh tutor dan pengelola dilakukan mulai dari identifikasi awal pembelajaran yaitu proses mengenali latar belakang dari peserta didik serta apa kebutuhan yang ingin dipenuhi oleh pserta didik ketika mengikuti proses pembelajaran. Selanjutnya menyusun kesepakatan sebagai wujud kolaborasi antara peserta didik dan tutor dan pengelola untuk menciptakan pembelajaran kondusif. Dan akhirnya proses-proses perencanaan untuk proses pembelajaran orang dewasa memang penting dilaksanakan guna mendapatkan hasil yang maksimal dan pembelajaran yang kondusif.
\end{abstract}

Kata Kunci: Pendidikan Orang Dewasa, Pendidikan Kesetaraan, Perencanaan Pembelajaran

\section{THE STUDY OF ADULT EDUCATION PLANNING ON EQUALITY EDUCATION IN COMMUNITY LEARNING CENTER JAYAGIRI LEMBANG}

\begin{abstract}
This study aims to reveal the process of adult education-based learning planning on the implementation of Equivalency Education. The method used in this study is qualitative with the type of research is a case study. The findings of this study indicate that the learning applied in the program is done with the approach of adults with the characteristics of students are adults. Planning activities undertaken by tutors and managers are done starting from the identification of early learning is the process of recognizing the background of learners as well as what needs to be met by the students while following the learning process. The process of arranging agreement as a form of collaboration between learners and tutors to create conducive learning. And finally the planning processes for adult learning process is important to be implemented in order to obtain maximum results and conducive learning.
\end{abstract}

Keywords: Adult Education, Educational Equality, Learning Planning

\section{PENDAHULUAN}

Pendidikan adalah modal dasar pembangunan Indonesia. Pendidikan merupakan salah satu cara mengatasi problema pembangunan saat ini. Isu mengenai pendidikan tidak akan pernah habisnya menjadi sebuah perbincangan di tengah masyarakat. Pendidikan yang dikenal saat ini terbagi menjadi tiga di antaranya adalah
Pendidikan Formal, Pendidikan Nonformal, dan Pendidikan Informal. Hal ini sesuai dengan Undang-Undang No. 20 tahun 2003 tentang Sistem Pendidikan Nasional menyebutkan bahwa pendidikan diselenggarakan melalui 3 jalur, yaitu pendidikan formal, nonformal, dan informal. Dalam tataran keilmuan Pendidikan Luar Sekolah 
Pendidikan Nonformal dan Informal menjadi salah satu kajian di dalamnya.

Ada yang menjadi ciri khas daripada pembelajaran pada pendidikan luar sekolah yaitu pendidikan orang dewasa. Di mana hal itulah yang menjadi salah satu kekhasan pada kegiatan pendidikan luar sekolah. Pendidikan Orang Dewasa yang seringkali dikenal sebagai Andragogi seperti yang diungkapkan oleh Knowles, Holton III \& Swanson (2005) bahwa andragogi adalah seni dan ilmu untuk membantu orang dewasa belajar.

Dalam kegiatan pendidikan luar sekolah salah satu komponen yang mengembangkan kegiatan pendidikan luar sekolah adalah Pusat Kegiatan Belajar Masyarakat (PKBM). Di PKBM sendiri banyak sekali kegiatan pendidikan nonformal di antaranya adalah Program Kesetaraan Paket C. Dalam hal ini lokasi yang menjadi rujukan dalam pembahasan ini adalah Program Kesetaraan Paket C yang ada di Pusat Kegiatan Belajar Masyarakat (PKBM) Jayagiri Lembang Lembang Bandung.

Berdasarkan Observasi Awal dengan salah satu Tutor Kesetaraan Paket C di PKBM ini menerapkan model pendidikan orang dewasa dalam kegiatan pendidikannya, salah satunya adalah Warga Belajar pada program kesetaraan paket $\mathrm{C}$ di PKBM Jayagiri Lembang dapat menentukan kapan dimulainya pelajaran dan apa saja yang akan dipelajari hal ini dikarenakan para warga belajar memiliki kesibukan sendiri. Maka karena alasan itulah PKBM ini menerapkan proses pembelajaran orang dewasa.

Berdasarkan paparan di atas diketahui bahwa Program Kesetaraan Paket $\mathrm{C}$ di PKBM Jayagiri Lembang menerapkan model pembelajaran Andragogi. Dalam kegiatan pembelajaran sudah pastilah memiliki perencanaan sebagai salah satu bagian yang tidak terpisahkan, begitu pula dengan kegiatan pendidikan orang dewasa juga memiliki kegiatan perencanaan. Sehingga pada penelitian ini akan mengungkap secara lebih lanjut mengenai Perencanaan pembelajaran berbasis orang dewasa pada Program Kesetaraan Paket C Kelas Karyawan di PKBM Jayagiri Lembang Bandung. Sehingga nantinya akan diperoleh gambaran jelas seperti apakah perencanaan pembelajaran berbasis orang dewasa yang diadopsi oleh PKBM Jayagiri Lembang ini.

Program Kesetaraan Paket C pada Pusat Kegiatan Belajar Masyarakat di Jayagiri Lembang Bandung memiliki karakteristik pembelajaran berbasis orang dewasa. Pembelajaran berbasis orang dewasa memiliki perbedaan yang mencolok, di mana pembelajaran orang dewasa berdasarkan apa yang dimiliki oleh orang dewasa itu sendiri. Berdasarkan pengembangan dari pemikiran Knowles, Holton III \& Swanson (2005) pendekatan pembelajaran orang dewasa (pendekatan andragogi) dibangun di atas beberapa asumsi, yaitu: Pertama, orang dewasa belajar karena kebutuhan untuk tahu. Kedua, Orang dewasa memiliki konsep diri sebagai pribadi yang mandiri, artinya bahwa dia memandang dirinya sudah mampu untuk sepenuhnya mengatur dirinya sendiri. Ketiga, Orang dewasa memiliki banyak (kaya) pengalaman yang cenderung berbeda sebagai akibat dari latar belakang kehidupannya. Keempat, Orang dewasa memiliki kesiapan tertentu (sesuai dengan peran sosialnya) untuk belajar. Kelima, Orang dewasa cenderung untuk mempunyai perspektif untuk secepatnya mengaplikasikan apa yang mereka pelajari. Keenam, orang dewasa belajar karena ada motivasi tertentu yang mempengaruhinya. Semua asumsi tersebut membawa implikasi tertentu yang sangat penting untuk diperhatikan dalam upaya pembelajaran orang dewasa, sehingga dalam prakteknya dilihat dari segi perencanaan pembelajaran berbasis orang dewasa sendiri memiliki hal khusus yang dapat dipengaruhi oleh konsep pendidikan orang dewasa itu sendiri. Pendidikan orang dewasa memiliki metode yang fleksibel sebagaimana telah disebutkan oleh Knowles, Holton III \& Swanson (2005) bahwa Andragogi bukan merupakan ideologi yang harus diterapkan benar-benar dan tanpa modifikasi. Bahkan, 
fitur penting dari andragogi adalah fleksibilitas, sehingga jelas sekali bahwa setiap aspek dalam kegiatan pendidikan orang dewasa benar-benar harus dilaksanakan dengan keseriusan begitu pula dengan kegiatan perencanaan pembelajaran harus benar benar dilakukan dengan jelas.

\section{METODE}

Penelitian ini akan menganalisis perencanaan pembelajaran berbasis orang dewasa pada program Kesetaraan Paket C PKBM Jayagiri Lembang, Lembang Bandung serta menggambarkan Pola Kolaborasi antara Pendidik dan Peserta Didik Orang Dewasa dalam perencanaan pembelajaran. Oleh karena itu, Penelitian ini menggunakan pendekatan kualitatif deskriptif yaitu dengan menelaah kasus yang ada serta menafsirkan hasil dari pengumpulan dan informasi. Alasan menggunakan pendekatan kualitatif adalah kajian mengenai proses perencanaan pembelajaran berbasis pada pendidikan orang dewasa, hal itu maka perlu penggalian informasi yang lebih dalam untuk mengungkap fakta tersebut guna mendapatkan informasi yang sebanyakbanyaknya. Analisis deskriptif yang dipilih digunakan untuk menganalisis serta menggambarkan perencanaan pembelajaran berbasis orang dewasa pada Program Kesetaraan Paket C kelas karyawan PKBM Jayagiri Lembang Lembang Bandung.

Lokasi untuk penelitian ini adalah PKBM Jayagiri Lembang bertepat di Jalan Jayagiri nomor 63 Lembang, Kab. Bandung Barat. Berdasarkan pengumpulan data awal, PKBM ini telah menerapkan konsep pembelajaran andragogi (Pendidikan Orang Dewasa). Karena alasan tersebutlah, maka PKBM ini yang dijadikan lokasi penelitian.

Prosedur pengumpulan data pada kajian ini dengan menggunakan beberapa teknik. Di antaranya, wawancara dan studi dokumen. Wawancara dilakukan dengan penyelenggara kegiatan pembelajaran yaitu para Tutor Program Kesetaraan Paket C untuk kelas karyawan. Sedangkan untuk studi dokumen terkait dengan dokumen- dokumen pendukung kajian berupa dokumen program Kesetaraan Paket C.

\section{HASIL DAN PEMBAHASAN}

\section{Pendidikan Orang Dewasa dan Perencanaan Pendidikan}

Andragogi selalu dihubungkan dengan pendidikan untuk orang dewasa, hal itu dipertegas oleh Aeby \& Aeby (2013) bahwa Andragogi dilihat sebagai karakteristik pembelajaran orang dewasa. Sebagaimana telah disebutkan oleh Knowles, Holton III \& Swanson (2005) bahwa Andragogi merupakan sebuah seni yang mengarahkan orang dewasa belajar. Selama ini Andragogi dikaitkan dengan pendidikan orang dewasa, hal ini dikarenakan andragogi lebih membahas mengenai cara untuk membelajrkan orang dewasa. Herod (2012) mengemukakan salah satu alasan bahwa andragogi telah dikenal sebagai "pembelajaran orang dewasa", andragogi memandang bahwa orang dewasa umumnya cenderung menjadi lebih jauh daripada anak-anak dalam hal pengembangan intelektual mereka, atau setidaknya dianggap lebih mampu. Andragogi merupakan salah satu pilar pendidikan orang dewasa. Berdasarkan hal itulah maka pembahasan mengenai andragogi lebih banyak mengungkap mengenai pendidikan orang dewasa. Pendidikan orang dewasa merupakan proses pendidikan yang diselenggarakan bisa dimana saja, Misalnya menurut Onyenemezu \& Amazu (2012) Pendidikan orang dewasa sebagai bagian integral dari pendidikan, mengacu pada proses belajar baik formal, informal atau non-formal yang dewasa terlibat dalam pembangunan yang lebih baik. Ini menekankan segala bentuk program pendidikan fungsional untuk pemuda dan orang dewasa di luar sistem sekolah formal.

Pendidikan Orang Dewasa menurut Adediran, Amos, \& Adenike (2013) bisa dilihat sebagai semua bentuk pendidikan atau proses yang melibatkan orang dewasa sepanjang hidupnya untuk menjaga pengetahuan mereka agar terus berkem- 
bang, memperluas cakrawala mereka sehingga untuk terpenuhinya pemahaman hidup mereka. Dari konsep itulah diketahui bahwa pendidikan orang dewasa merupakan salah satu kegiatan pendidikan yang dalam prosesnya melibatkan peran orang dewasa sebagai peserta didik secara penuh. Selain itu Obasi (2014) menyatakan bahwa Pendidikan orang dewasa termasuk pendidikan dasar dan berkelanjutan, pendidikan kejuruan dan teknis, pendidikan tinggi dan pengembangan profesional, itu ditawarkan melalui formal, non-formal dan informal dan oleh berbagai pelaku pendidikan.

Pendapat lain mengenai orang dewasa diungkapkan oleh Unesco (Hussain \& Halladu, 2013) bahwa pendidikan orang dewasa merupakan seluruh proses pembelajaran yang berlangsug secara resmi atau sebaliknya, di mana orang dewasa mengembangkan kemampuan mereka, memperkaya pengetahuan mereka, dan meningkatkan kualifikasi teknis atau profesional mereka atau mengubahnya ke arah yang baru untuk memenuhi kebutuhan mereka sendiri dan kebutuhan sebagai bagian dari masyarakat. Onyenemezu (2012) menambahkan Pendidikan orang dewasa proses mendidik peserta didik dewasa tentang cara-cara yang lebih baik untuk mengelola sumber daya yang tersedia untuk mencapai keberhasilan sosial-politik dan ekonomi dalam upaya hidup mereka dan juga membuat arahan yang membantu kepribadian individu dan lembaga dalam menangani masalah manusia serta masyarakat di mana mereka menemukan diri mereka.

Pendidikan orang dewasa memiliki objek kajian yang terletak pada kekhususan sasaran yaitu orang dewasa, sehingga memiliki karakteristik tertentu yang membedakan seperti apa orang dewasa orang dewasa tersebut. Ugwu (Onyenemezu \& Amazu, 2012) menguraikan karakteristik utama yang melekat pada orang dewasa: a) Orang Dewasa telah mengumpulkan pengetahuan dan kekayaan pengalaman di berbagai bidang; b) Orang Dewasa adalah orang-orang dewasa yanghidup dengan potensi fisik, psikologis, sosial, moral, ekonomi, politik, budaya dan sipil yang membuat mereka berkembang dengan baik di masyarakat; c) Orang Dewasa relevan berorientasi karena mereka selalu ingin tahu alasan-alasan di balik apa yang pernah mereka ingin lakukan.

Dalam pengembangan pendidikan orang dewasa haruslah mengacu pada karakteristik orang dewasa. Sehingga hal itu akan lebih menghasilkan kesuksesan dalam kegiatan pembelajaran. Orang dewasa memiliki perbedaan dalam segala hal. Orang dewasa dianggap sebagai objek khusus dalam hal pelayanan pendidikan. Begitupula kekhususan praktek dalam pendidikannya juga akan berpengaruh pada proses perencanaan kegiatan pembelajaran (Hensckhe, 2011).

Perencanaan merupakan langkah awal dari suatu kegiatan, seperti yang telah dijabarkan oleh Kowalski (1998) yaitu perencanaan adalah prosedur formal yang digunakan untuk membuat program. itu berorientasi ke masa depan dan merupakan langkah pertama dalam menciptakan program. Kegiatan pembelajaran juga haruslah memiliki prosedur perencanaan yang tepat agar kegiatan pembelajaran berhasil.

Adapun langkah yang meski ditempuh dalam kegiatan perencanaan kegiatan pembelajaran orang dewasa, London (Kowalski, 1998) membagi langkah perencanaan tersebut menjadi lima, di antaranya adalah a) Menentukan kebutuhan peserta didik; b) Meminta partisipasi mereka; c) Merumuskan tujuan yang jelas; d) Merancang sebuah program; e) Merencanakan dan melaksanakan sistem evaluasi.

Pendapat lain yang hampir mirip digambarkan oleh Knowles, Holton III \& Swanson (2005) adalah a) Menentukan apa yang dibutuhkan oleh peserta didik untuk dipelajari b) Membuat strategi dan sumber daya untuk mencapai tujuan pembelajaran c) Menerapkan strategi pembelajaran dan sumber belajar apa yang akan digunakan. d) Menilai pencapaian tujuan pembelajaran dan proses pembelajaran tersebut. 
Ada pula pendapat dari Northwest Center for Public Health Practice (2012) menyebutkan ada beberapa hal yang dilakukan dalam pendidikan orang dewasa diantaranya adalah: Pendahuluan, yaitu a). Mengenali peserta didik setidaknya nama dan latar belakang pekerjaannya hal ini digunakan untuk menentukan kebutuhan belajar serta menentukan dari sekian banyak peserta didik apakah perlu bimbingan khusus, b.) Menentukan tujuan pembelajaran untuk memetakan perubahan apa yang akan di capai oleh peserta didik (Pengetahuan, Keterampilan, Sikap), c). Menentukan jenis pembelajaran apa yang akan dikembangkan.

Kemudian, mengembangkan konten pembelajaran, termasuk menentukan metode apa yang cocok untuk pembelajaran. Selanjutnya adalah menyiapkan aplikasi strategi pembelajaran yang telah disusun.

Pada kajian dengan topik perencanaan pembelajaran berbasis orang dewasa ini hal yang akan dikaji secara lebih lanjut adalah mengenai proses perencanaan menggunakan gabungan dari teori perencanaan yang hanya berfokus pada 1) Identifikasi karakter peserta didik; 2) Proses perencanaan dalam hal menciptakan strategi dan pemanfaatan sumber belajar; 3) Proses perencanaan dalam mengevaluasi hasil belajar.

Dalam perencanaan berbasis orang dewasa, peserta didik haruslah diikutsertakan (perlu adanya partisipasi) dalam perencanaan pembelajaran sebagaimana yang telah disebutkan oleh Cohen dan Uphoff (Baba et al., 2011) menyatakan bahwa partisipasi yang diharapkan dari peserta dalam kegiatan pembangunan termasuk pendidikan orang dewasa adalah partisipasi dalam pengambilan keputusan pada perencanaan kegiatan, implementasi, memperoleh keuntungan pembangunan (penyuluhan) dan evaluasi kegiatan. Di mana hal ini disebabkan oleh faktor pendidikan orang dewasa yang berbasisi kebutuhan. sebagaimana Ife \& Tesoriero (2008) bahwa partisipasi juga menyebabkan mobilisasi psikis dan fisik (perubahan pengetahuan, sikap dan perilaku) peserta didik berjalan dengan cepat karena program yang dilaksanakan sesuai dengan kebutuhan, prioritas dan kondisi sumber daya yang dimiliki. Maka dalam perencanaan pendidikan orang dewasa diperlukan kolaborasi antara pendidik dan peserta didik untuk mewujudkan kesuksesan dalam kegiatan pendidikan tersebut.

\section{Proses Perencanaan Berbasis Pendidikan Orang Dewasa}

Program Kesetaraan Paket C (Setara SMA) di PKBM Jayagiri terdiri dari jenis kesetaraan yang dibuka yaitu Kesetaraan Untuk Kelas Reguler dan Kelas Karyawan. Ada perbedaan antara kelas reguler dan kelas karyawan, dilihat dari model belajar dan peserta didik tentunya. Pada kelas reguler terdiri dari para peserta didik dari usia sekolah dan proses belajar memang didesain seperti sekolah reguler termasuk seragam yang dikenakan oleh peserta didiknya. Berbeda dengan yang kelas karyawan sebagaimana diketahui bahwa kelas karyawan pada umumnya terdiri dari para karyawan di berbagai instansi. Kegiatan perencanaan yang dilakukan oleh para tutor dan pengelola program adalah sebagai berikut:

a. Identifikasi Awal Pembelajaran

Pada kegiatan perencanaan tahap pertama adalah mengenali peserta didik yang akan menjadi bagian dari kegiatan pembelajaran. Hal yang dilakukan oleh para Tutor adalah pengenalan latar belakang dari peserta didik, di antaranya mengenali instansi tempat di mana peserta didik tersebut bekerja. Proses mengenali latar belakang pekerjaan ini dilakukan oleh para Tutor pada waktu mendaftar untuk menjadi peserta didik Program Kesetaraan Paket C. Hal ini dilakukan untuk mengetahui di mana asal sebagai langkah awal pengenalan calon peserta didik yang akan diberi layanan pendidikan orang dewasa.

Para Tutor biasanya mengajak peserta didik berbagi pengalaman. Biasanya berisi sharing pengalaman tentang pekerjaan sehari-harinya, apa 
yang mereka belum bisa. Hal ini dilakukan oleh tutor untuk pemantapan dan penilaian terhadap karakteristik peserta didik. Selain itu mereka berbagi alasan mengapa mengikuti kegiatan kesetaraan, di mana para peserta didik memang dituntut untuk memiliki Ijasah yang setara dengan SMA sebagai salah satu kebutuhan dari peserta didik. Hal ini digunakan karena memang sebagai tuntutan dari instansi/perusahaan yang mengharuskan pengetahuan tersebut. selain itu biasanya mereka termotivasi untuk mendapatkan Ijazah setara pendidikan sekolah yang didapat tidak dari pendidikan formal karena kesibukan dan beberapa faktor yang tidak memungkinkan mereka untuk sekolah. Ijazah tersebut penting bagi mereka untuk meningkatkan tunjangan gaji bahkan digunakan untuk menaikkan pangkat mereka.

\section{b. Menciptakan Strategi Belajar}

Setelah mengetahui karakteristik peserta didik, kemudian melakukan kesepakatan bersama untuk kegiatan pembelajaran. Peserta didik untuk kelas karyawan ini memiliki latar belakang tempat kerja yang berbeda sehingga kesiapan belajar mereka juga berbedabeda, untuk mendapatkan kesepakatan tersebut maka pihak PKBM menyusun strategi yaitu dengan mengirim surat pemberitahuan kelas yang memuat rencana jadwal belajar dari situlah kemudian peserta didik menentukan tanggal dimulai belajarnya, biasanya mereka belajar di hari libur, seperti hari sabtu dan hari minggu bahkan hari libur nasional. Karena pada waktu itu mereka biasanya memiliki banyak kelonggaran untuk belajar.

Dari adanya pemetaan akan karakteristik latar belakang pekerjaan peserta didik diketahui gaya belajar peserta didik seperti misalnya karena tuntutan pekerjaan yang menyita waktu ditambah jarak antara PKBM dan Tempat Kerjanya yang jauh mereka kelelahan dan banyak kesibukan kadang peserta didik biasanya jenuh dengan materi yang diajarkan. Maka tutor merencanakan strategi pembelajaran yang tidak hanya dikelas. Salah satu strategi yang digunakan yaitu belajar diluar kelas, karena mereka bisa berekspresi lebih banyak diluar kelas. Misalnya belajar sambil minum kopi. Atau misalnya peserta didik untuk melakukan kunjungan ke beberapa tempat untuk melakukan kegiatan yang mendukung terserapnya apa yang diajarkan secara teori. Lamanya belajar selama satu hari itu juga disesuaikan dengan seberapa kuat peserta didik untuk menerima materi yang disampaikan. Strategi ini dilakukan untuk membuat peserta didik tetap mengikuti kegiatan pembelajaran, sebagaimana menurut menurut Dick \& Robert (1990) strategi pembelajaran adalah suatu pendekatan dalam mengelola secara sistematis kegiatan pembelajaran sehingga warga belajar dapat mencapai isi Pembelajaran Orang Dewasa atau mencapai tujuan seperti yang diharapkan.

Strategi pembelajaran yang dicoba oleh Tutor sebagai bagian dalam membuat peserta didik untuk terus mengikuti kegiatan kesetaraan paket c hingga tuntas. Maka disusunlah strategi yang memungkinkan peserta didik tidak akan jenuh pada materi pembelajaran, serta mencipatakan iklim pembelajaran yang kondusif.

\section{Kolaborasi Antara Peserta Didik Dengan Tutor Dalam Kegiatan Perencanaan}

Kolaborasi yang terjadi antara Peserta Didik dengan Tutor dalam rangka kegiatan perencanaan Program Kesetaraan Paket C dimulai dari identifikasi karakteristik peserta didik. Diketahui bahwa proses identifikasi kebutuhan ini dimulai dari kegiatan pendaftaran. Peserta datang mendaftar untuk mengikuti program Kesetaraan Paket C. Hasil dari identifikasi kebutuhan itulah yang dijadikan alat untuk melakukan 
pemetaan latar belakang peserta didik oleh para tutor pendidikan kesetaraan.

Pada identifikasi karakter peserta didik tidak ada kolaborasi antara peserta didik dengan Tutor. Kegiatan identifikasi ini dilakukan oleh tutor saja sedangkan peserta didik secara pasif dalam melakukan kerjasama (Kolaborasi). Tutor mengkaji hasil dari identifikasi tersebut untuk menentukan karakter dari calon peserta didik di pendidikan kesetaraan tersebut. Adapun keseluruhan kegiatan perencanaan ini dapat digambarkan sebagai berikut:

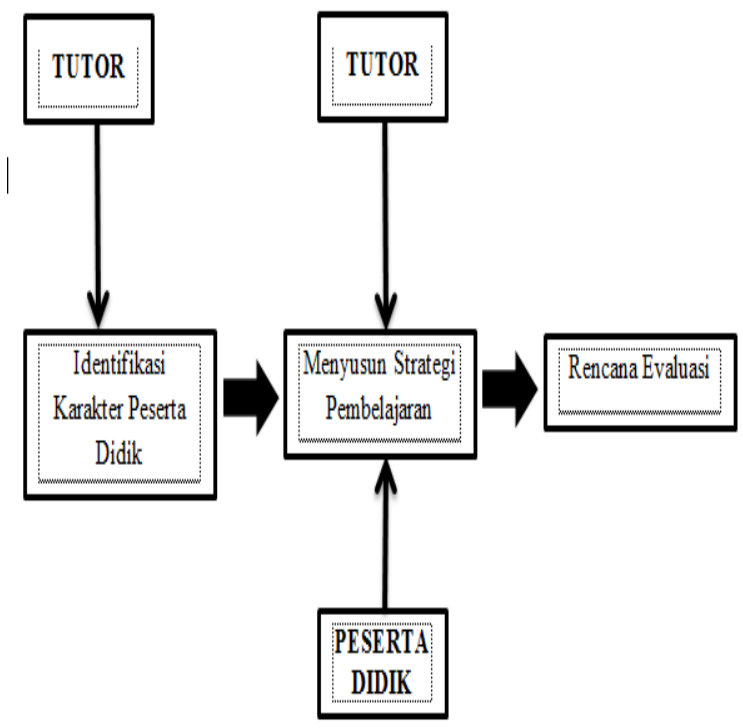

(Hasil wawancara dengan pengelola)

Gambar 1. Gambaran Perencanaan

Pembelajaran Program Kesetaraan Paket C di PKBM Jaya Giri

Kegiatan perencanaan dalam menentukan strategi pembelajaran yang dilakukan oleh tutor dan peserta didik menentukan jadwal kegiatan pembelajaran. Peserta didik diminta untuk menentukan kapan mulai kegiatan pembelajaran. Peserta didik berpartisipasi dalam menyusun jadwal kegiatan pembelajaran.

Pada kegiatan pembelajaran untuk menciptakan iklim pembelajaran yang kondusif ada kolaborasi antara peserta didik dengan tutor. Adanya kebebasan memilih gaya belajar oleh peserta didik agar kegiatan pembelajaran tidak menjenuhkan. Tutor memberikan kesempatan berekspresi bagi para peserta didik agar tetap melakukan kegiatan pembelajaran. Peserta didik secara aktif ikut serta dalam kegiatan pembelajaran.

\section{PENUTUP}

Penelitian mengenai perencanaan Program Kesetaraan Paket C ini mengungkapkan beberapa hasil penelitian seperti diketahui bahwa karakteristik peserta didik pada Program Kesetaraan Paket $\mathrm{C}$ ini adalah para karyawan maupun satpam yang sebelumnya belum memilki ijasah setara SMA. Proses perencanaan yang dilakukan oleh tutor dan pengelola Pada kegiatan perencanaan tahap pertama adalah mengenali peserta didik yang akan menjadi bagian dari kegiatan pembelajaran untuk mengetahui dimana asal sebagai langkah awal pengenalan calon peserta didik yang akan diberi layanan pendidikan orang dewasa. prosesnya dilakukan dengan berbagai pengalaman dengan para peserta didik. Setelah mengetahui karakteristik peserta didik, kemudian melakukan kesepakatan bersama untuk kegiatan pembelajaran.

Penelitian ini dapat dijadikan kajian lebih lanjut dalam penyelenggaraan Program Kesetaraan Paket C. Dengan mengkaji dari penelitian yang telah dilakukan ini juga dapat dijadikan sebagai penambah referensi dalam mengkaji keilmuan pendidikan orang dewasa. selanjutnya untuk penelitian yang akan datang yang dapat dilakukan adalah mengkaji lebih lanjut proses perencanaan Program Kesetaraan Paket $\mathrm{C}$ terlebih pada proses pendaftaran peserta didik ataupun pada proses pembelajaran yang dilakukan turor dan pengelola program.

\section{UCAPAN TERIMA KASIH}

Penelitian ini tidak akan selesai tanpa adanya pihak-pihak yang telah membantu dalam penyelesaian penelitian ini. Ucapan terima kasih diberikan kepada pengelola Program Kesetaraan Paket C PKBM Jaya Giri serta teman-teman yang telah meluangkan waktunya untuk dijadikan tempat diskusi sehingga penelitian ini dapat diselesaikan. 
DAFTAR PUSTAKA

Adediran, Amos, A, dan Adenike, O.C. (2013). Refocusing Adult Literacy, Non Formal Education And Long Life Learning Education For Multiliteracies In Africa. Journal of Education And Practice. Vol.4 (10), pp. 01-06.

Aeby, T.C. \& Aeby, V.G. (2013). Application of Andragogy to Instruction in an MSW Practice Class. Journal of Instructional Psychology. Vol. 40 ( 1), pp. 03-13.

Baba, S., Isbandi, Mardikanto, $\mathrm{T} \&$ Waridin. (2011). Faktor-Faktor Yang Mempengaruhi Tingkat Partisipasi Peternak Sapi Perah Dalam Penyuluhan Di Kabupaten Enrekang. Jurnal Ilmu Teknologi Peternakan. Vol. 01(03), pp. 195-205.

Dick, W \& Robert, A.R. (1990). Planning Effective Instruction. Boston: Allyn and Bacon.

Hensckhe, J.A. (2011). Considerations Regarding the Future of Andragogy. Adult Learning, 22 (01), pp. 34-37.

Herod, L. (2012). Adult Learning: From Theory to Practice. Kanada: The Canadian Adult Literacy Community.

Hussain, M.S. \& Haladu, N. (2013). Adult and Non-formal Education in the Global Context. Journal of Education and Practice, Vol. 04 (04), pp. 38-42.

Ife, J. \& Tesoriero, F. (2008). Community Development:

Alternatif

Pengembangan Masyarakat di Era Globalisasi. Yogyakarta: Pustaka Pelajar.

Knowles, M.S, Holton III, E.F., Swanson, R.A. (2005). The Adult Learner: The Deffinitive Classic in Adult Education and Human Resource Development. USA: Elsevier.

Kowalski, T. (1998). The Organization and Planning of Adult Education. New York: State University of New York Press, Albany.

Northwest Center for Public Health Practice. (2012). Effective Adult Learning: A Toolkit for Teaching
Adults. Washington: University of Washington School of Public Health. Obasi, S. (2014). Adult Education in Nigeria: A Discipline in Search of Scope and Direction?. Journal of Education and Practice. Vol. 05 (11), pp. 27-31.

Onyenemezu, E.C. (2012). Adult Education and the Challenges of the $21 \mathrm{St}$ Century in Nigeria. Journal of Education and Practice. Vol. 03 (05), pp. 01-06.

Onyenemezu, E.C. \& Amazu, C.C. (2012). Adult Education as a Tool for Nurturing Nigeria's Nascent Democracy. Journal of Education and Practice. Vol. 03 (05), pp. 07-15. Undang-undang No. 20 Tahun 2003 Tentang Sistem Pendidikan Nasional. 